\title{
Gender differences in trauma, shock and sepsis
}

\author{
Florian Bösch', Martin K. Angele ${ }^{1}$ and Irshad H. Chaudry ${ }^{2 *}$
}

\begin{abstract}
Despite efforts in prevention and intensive care, trauma and subsequent sepsis are still associated with a high mortality rate. Traumatic injury remains the main cause of death in people younger than 45 years and is thus a source of immense social and economic burden. In recent years, the knowledge concerning gender medicine has continuously increased. A number of studies have reported gender dimorphism in terms of response to trauma, shock and sepsis. However, the advantageous outcome following trauma-hemorrhage in females is not due only to sex. Rather, it is due to the prevailing hormonal milieu of the victim. In this respect, various experimental and clinical studies have demonstrated beneficial effects of estrogen for the central nervous system, the cardiopulmonary system, the liver, the kidneys, the immune system, and for the overall survival of the host. Nonetheless, there remains a gap between the bench and the bedside. This is most likely because clinical studies have not accounted for the estrus cycle. This review attempts to provide an overview of the current level of knowledge and highlights the most important organ systems responding to trauma, shock and sepsis. There continues to be a need for clinical studies on the prevailing hormonal milieu following trauma, shock and sepsis.
\end{abstract}

Keywords: Trauma-hemorrhage, Cardiopulmonary bypass, Gender morphism, Hormonal milieu, Estrogens

\section{Background}

Despite efforts in resuscitation measures and intensive care, acute trauma and the resulting shock and subsequent sepsis remain associated with a high mortality [1]. A great deal of work has also been done in the prevention of traumatic injury. Nevertheless, traumatic injury is the major cause of death in people younger than 45 years of age and thus remains a major public issue [2-4]. Traumatic brain injury (TBI) accounts for $25 \%$ of long-term disabilities in individuals younger than 35 years of age. With an estimated annual incidence of 1.7 million individuals in the United States and a cost of $\$ 76.1$ billion, TBI is a major social and economic burden $[3,5,6]$.

Severe blood loss, often linked to traumatic injury, is associated with a high morbidity and mortality. The US Armed Forces reported 4,596 battlefield deaths from 2001 to 2011. Of these casualties, only 13\% reached medical facilities prior to death. The authors

\footnotetext{
* Correspondence: IChaudry@uab.edu

${ }^{2}$ Center for Surgical Research and Department of Surgery, University of

Alabama at Birmingham, Birmingham, AL 35294, USA

Full list of author information is available at the end of the article
}

classified $24 \%$ of the premedical facility deaths as potentially survivable, of which $90 \%$ were due to severe hemorrhage $[7,8]$. Hemorrhagic shock and subsequent hypoperfusion to the body lead to hypoxia and eventual death. Therefore, controlling blood loss and administering resuscitative fluids are standard recommendations for the treatment of major blood loss [9]. In remote, distant military situations, management of hemorrhagic shock is challenging since large fluid volumes cannot be routinely supplied. Therefore, the US Department of Defense is supporting research to improve medical treatment on the battlefield [10]. In this respect, experimental animal studies have demonstrated that a single, small-volume infusion of ethinyl estradiol-3-sulfate (EES) has beneficial effects following trauma-hemorrhage, even in the absence of fluid resuscitation [11, 12].

Survivors of severe blood loss concomitant with trauma have a high risk of developing subsequent sepsis and multiple organ failure. Regardless of outstanding advances in the understanding and treatment of sepsis, the mortality rate remains at $30 \%[13,14]$. In the last decades, numerous studies have demonstrated gender

(c) The Author(s). 2018 Open Access This article is distributed under the terms of the Creative Commons Attribution 4.0 International License (http://creativecommons.org/licenses/by/4.0/), which permits unrestricted use, distribution, and 
dimorphism in response to trauma and sepsis with respect to immunological, cardiovascular and pathophysiological mechanisms [15-20]. Several studies have reported that women are less susceptible to posttraumatic infections and multiple organ failure [21-24]. A large body of evidence from animal studies definitively supports these findings [11, 12, 25-27]. The more favorable outcome in female patients following trauma and blood loss is mediated via sex hormones and in particular, the binding of estrogen to the estrogen receptors $[10,26,28,29]$.

Given the previously demonstrated gender differences following trauma and shock in experimental (in vitro as well as in vivo) and clinical studies, it is essential that future studies take gender into account. Since May of 2014, the National Institutes of Health $(\mathrm{NIH})$ accordingly requires information about the composition of cells and animal gender in preclinical studies.

In addition, there is an apparent genetic disparity since females carry two inherently polymorphic $\mathrm{X}$ chromosomes, while males have only one polymorphic $\mathrm{X}$ chromosome passed from the mother [30-33].

\section{Gender dimorphism in trauma, shock and sepsis}

As mentioned above, there is evidence for a gender dimorphism in the morbidity and mortality following trauma, hemorrhage and sepsis (Fig. 1). It was reported for the first time in 1975, that males are more prone to posttraumatic infections [34]. Since then, several studies have indicated that male gender and age are major risk factors for infections and multiple organ failure after trauma and blood loss [22, 23, 32-35].

Inflammation represents a common line of defense for maintaining the physiological homeostatic balance following infection or trauma. Subsequently, the inflammatory process leads to complex pro- and anti-inflammatory mechanisms. Additionally, the immune response to acute vs. chronic inflammatory processes is different and must be considered. In clinical reality, those acute and chronic inflammatory processes commonly together occur in the same patient (e.g., a patient with chronic pulmonary obstructive disease and involved in a car accident). This complexity in inflammatory processes, preexisting comorbidities and possible patient medication directly affects the inflammatory response. However, even highly sophisticated animal models cannot reflect this complexity of real life, which may account for other factors in addition to sex hormones, and thus contributes to divergent results between experimental and clinical studies. However, a further discussion of differences in the response to acute vs. chronic inflammatory disease processes is beyond the scope of this review.

The majority of studies also demonstrated an improved outcome in females after trauma. Interestingly, gender itself may not be an independent prognostic factor. Retrospective analyses revealed that female patients had a higher mortality rate if an infection or severe sepsis occurred after trauma [36-38]. In contrast to these findings, other studies reported a significantly better outcome for women after traumatic injury, severe blood loss and sepsis $[22,33,39]$. The contradictory findings are most likely because Eachempati et al. [36] and Napolitano et al. [37] did not consider age and prevailing hormonal

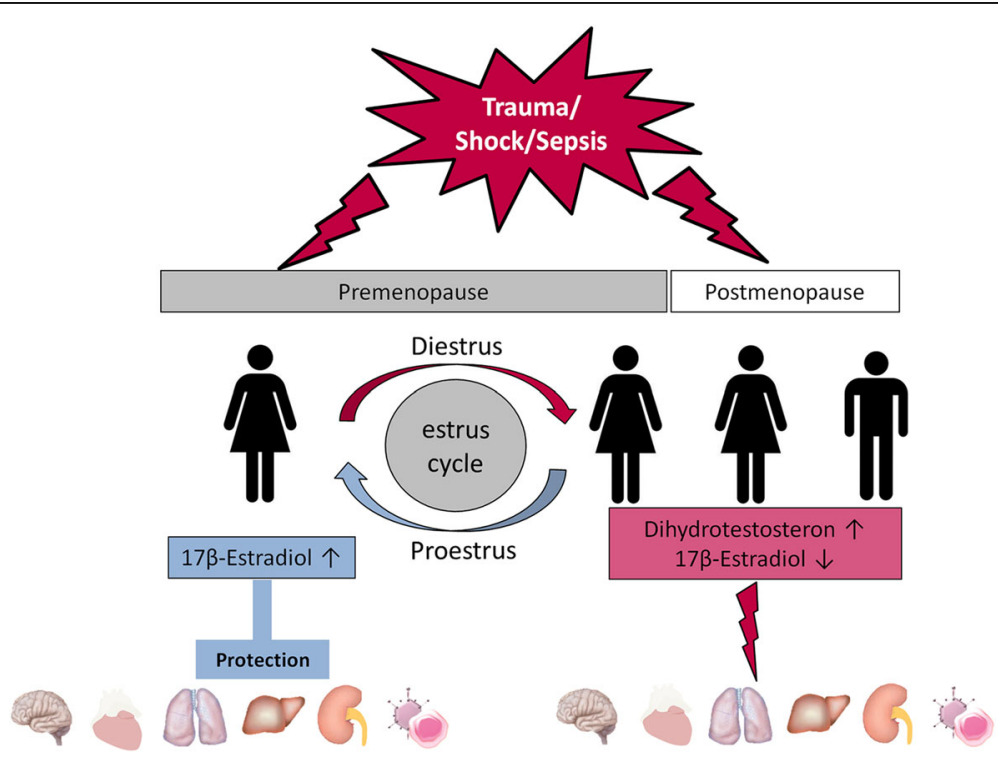

Fig. 1 Trauma, shock and sepsis have several deleterious effects on organ systems depending on gender and the prevailing hormonal milieu 
milieu as confounders. However, age may play a less important role at the time of injury than hormonal status since hormone blood levels differ significantly during the menstrual cycle. In a large multicenter analysis including more than 20,000 patients, the authors demonstrated a significant survival benefit for female patients younger than 50 years [40]. In accordance with these findings, posttraumatic sepsis and multiple organ failure was reduced in women when age was taken into account [41, 42]. In contrast to the abovementioned studies, clinical findings have demonstrated diminished survival in females following adverse circulatory conditions [43-46]. In this respect, the endocrine milieu in females is regularly influenced by the estrous cycle and by the onset of menopause. In the United States, the average onset of menopause occurs at the age of 50 years [47]. Thus, it is important that age and the prevailing hormonal status be taken into account as a first step in all gender-related studies. Furthermore, exogenous hormones are frequently administered and further influence the hormonal status. The intake of oral contraceptives and hormone replacement therapy is not documented in most clinical studies investigating gender-specific outcomes in critically ill patients. It is estimated that $21 \%$ of the women in the United States take hormone replacement therapy, which represents a substantial percentage of female patients [48]. Since no studies were stratified by exogenous hormone treatment or the phase of the estrous cycle, prospective clinical studies in trauma victims that take into account the hormonal status at the time of injury are needed.

\section{The central nervous system}

As mentioned above, sex differences in the immune system and the inflammatory response are evident. Glial cells of the central nervous system are key players in the inflammatory response. These cells mediate the immune response by an inflammatory cytokine burst consisting of tumor necrosis factor $\alpha$ (TNF- $\alpha$ ), prostaglandin $E_{2}$ and interleukin-1 $\beta$ (IL-1) [49-51]. The secretion of proinflammatory cytokines is a major step in the deleterious cascade of traumatic brain injury following intra- and extracerebral bleeding, contusion and swelling. This cascade ends in destruction of the blood-brain barrier, reduced cerebral blood flow and necrosis of neuronal cells $[52,53]$.

There is evidence that after endotoxin injection, female rodents can attenuate systemic inflammation through a reduction of the hypothalamic IL-1 response [54]. This finding is further supported by the fact that the effects of IL-1 administration are estrous cycle-dependent [55]. Moreover, ovariectomy leads to increased IL-1 levels, which can in turn be reduced by administration of estradiol benzoate [56].
Studies have also shown that administration of estrogen 1 hour following traumatic brain injury produces various beneficial effects, such as markedly reduced cerebral edema, decreased neuronal degeneration and improvement of memory and cognitive functions [5759]. Furthermore, studies have shown that estrogen administration following spinal cord injury also produces salutary effects $[60,61]$.

\section{The cardiovascular system}

Severe trauma-hemorrhage associated with hemorrhagic shock is a major cause of death [4]. Preservation of cardiac function and vascular responsiveness is crucial for maintaining hemodynamic stability. To achieve stability, fluid management and the use of vasopressors and inotropes are established in intensive care medicine. In this regard, studies have shown that administration of estrogen sulfate following severe blood loss improves outcomes in hemorrhagic shock models [11, 12]. Additionally, following severe blood loss, exogenous estradiol administration exerted protective effects and improved myocardial function, as well as vascular responsiveness [62, 63].

The beneficial effects may be explained by the altered expression levels of heat shock proteins (HSPs) following estrogen administration. The main role of HSPs is to protect cells, and they therefore play an important role in protein folding, apoptosis and signaling [64]. Expression of HSP70 is increased in response to severe blood loss, subsequently leading to a reduced rate of myocardial necrosis [65]. It has been demonstrated that estradiol administration improves cardiac function via upregulation of HSP expression [66-68].

Additionally, Szalay et al. showed that estradiol induces heme oxygenase-1 (HO-1) expression [67]. HO-1 is the rate-limiting enzyme in the degradation of heme into the bioactive signaling molecules free iron, biliverdin and carbon monoxide. In this regard, previous studies have shown that induction of $\mathrm{HO}-1$ and its products exert cardioprotective effects [69, 70].

There is further compelling evidence of a gender dimorphism in the incidence of cardiovascular disease. Males are more prone than females to develop cardiovascular disease and to experience sudden cardiac death [71-73].

\section{The respiratory system}

Patients are highly susceptible to sepsis and multiple organ failure after severe trauma-hemorrhage. Cytokines and adhesion molecules mediate neutrophil infiltration to the lung and subsequent inflammation. These molecules are mainly cytokine-induced neutrophil chemoattractant 1 (CINC-1), CINC-3 and intercellular adhesion molecule 1 (ICAM-1) [74]. Studies have revealed that high levels of female sex hormones 
attenuated the pulmonary inflammatory response to severe blood loss $[75,76]$. Moreover, exogenous estradiol administration mimicked these protective effects in male mice following trauma-hemorrhage. Male animals showed significantly less pulmonary edema and neutrophil infiltration following trauma-hemorrhage and estrogen administration [77]. In accordance with these findings, Doucet et al. demonstrated that ovariectomy had deleterious effects on lung injury following severe blood loss. However, exogenous estradiol administration in those animals could in part improve pulmonary function [78].

The underlying mechanism(s) of the salutary effects of estradiol administration have not been fully elucidated. However, it has been shown that extracellular signal-regulated (ERK) protein kinase partially mediates these effects. Male rats subjected to trauma-hemorrhage showed increased ERK phosphorylation, lung myeloperoxidase activity, and increased levels of IL-6, TNF- $\alpha$, ICAM-1 and CINC-1, which were attenuated by estradiol administration following trauma-hemorrhage [79].

\section{The hepatic system}

Multiple organ failure subsequent to trauma-hemorrhage, shock and sepsis remains the major cause of death. It is well known that the maintenance of normal hepatic function is pivotal for outcomes following severe traumatic injury [80-82]. Cytokine-mediated tissue inflammation is the first step in the development of sepsis and profound organ damage. Similar to other organ systems, there is also a gender dimorphic response to hepatic injury following trauma-hemorrhage [83-85].

Kupffer cells are hepatic macrophages located in the liver sinusoids and are an important source of proinflammatory chemokines, such as IL-6, IL-10, and TNF- $\alpha$. It was demonstrated that estradiol treatment downregulated the proinflammatory cytokine burst following trauma-hemorrhage $[86,87]$. The salutary effects of post-treatment with estradiol are in part mediated via the p38 mitogen activated protein kinase (MAPK)-dependent HO-1 pathway. Several lines of evidence have established the beneficial effects on hepatic HO-1 induction [88-90]. Severe trauma-hemorrhage resulted in significantly decreased p38 phosphorylation in the liver. Estradiol treatment following trauma-hemorrhage increased p38 phosphorylation and $\mathrm{HO}-1$ induction and attenuated apoptosis. Conversely, administration of a p38 MAPK inhibitor prevented p38 phosphorylation and the increase in HO-1 induction [91].

An additional pathway by which exogenous estradiol exerts its salutary effects following low flow conditions has been shown in further studies. Toll-like receptor 4 (TLR4) is a crucial player in mitochondrial DNA damage and mediates proinflammatory chemokine release [92]. Trauma- hemorrhage led to an increase in TLR4 expression, which was associated with a release of proinflammatory cytokines. However, administration of estradiol following traumahemorrhage decreased p38 phosphorylation, as well as levels of the proinflammatory cytokines IL-6, TNF- $\alpha$, macrophage inflammatory protein- $1 \alpha$ (MIP- $1 \alpha)$ and MIP-2. Furthermore, estradiol normalized the levels of inducible nitric oxide synthase (iNOS) and adenosine triphosphate (ATP) [92, 93]. In this regard, increased iNOS activity is observed following hepatic tissue injury and is known to be detrimental [94].

According to findings in the cardiovascular system, HSP induction should also be protective following hepatic injury [95]. It was shown that estradiol administration following trauma-hemorrhage induced HSP expression in the injured liver $[67,96,97]$. These findings suggest that the protective effects of estradiol are in part mediated via HSP expression. Furthermore, the reported beneficial effects of estradiol in the hepatic system are mediated via estradiol receptor- $\alpha$ (ER- $\alpha)$ [98]. This was further confirmed by the findings that an ER- $\alpha$ agonist, propyl pyrazole triol (PPT), evoked salutary effects following trauma-hemorrhage. PPT reduced the expression of iNOS, NF- $\mathrm{kB}$ and activating protein-1 (AP-1), which are detrimental through their release of proinflammatory chemokines [95]. Moreover, the administration of flutamide, an androgen receptor antagonist, following traumahemorrhage prevented hepatic injury in rats subjected to hemorrhagic shock. The salutary effects of flutamide were partially mediated by the estrogen receptor pathways [99]. In addition to ER- $\alpha$ mediated signaling, another estrogen receptor, G protein-coupled receptor 30 (GPR30), has been revealed to play a role in trauma-hemorrhage. GPR30 acts independently of ER and mediates the nongenomic salutary effects of estradiol. Following traumahemorrhage, GPR30 acts in a protective manner via the protein kinase A pathway. Alternatively, GPR30 suppression leads to increased apoptosis [100].

\section{The renal system}

Trauma and shock lead to impaired organ function and are associated with a high morbidity and mortality. Acute kidney injury (AKI) is seen in up to $70 \%$ of patients with septic shock. Among these patients, the mortality rate reaches nearly $50 \%[101,102]$. Furthermore, a frequent type of AKI is ischemia-reperfusion injury (IRI). Impaired renal function subsequent to IRI is due to tubular cell damage, apoptosis and the release of proinflammatory cytokines [103-105]. In this respect, studies have revealed gender dimorphism in the susceptibility to AKI. Administration of estradiol attenuated renal IRI whereas testosterone enhanced IRI [106, 107]. Furthermore, administration of estradiol reduced apoptosis and inflammation, and increased endothelial cell survival 
[108]. Additionally, the levels of proinflammatory TNF- $\alpha$ were reduced and levels of anti-inflammatory IL-10 were increased when estradiol was administered following trauma-hemorrhage. The modulated immune response appears to be due to a decreased number of infiltrating neutrophils $[108,109]$.

\section{The immune system}

In several disease processes, gender and sex hormones have been shown to affect immunological responses. In this respect, enhanced humoral and cell-mediated immune responses in females are associated with an increased incidence of autoimmune and certain inflammatory diseases (i.e., Hashimoto's thyroiditis, systemic lupus erythematosus, rheumatoid arthritis, primary biliary cirrhosis and asthma). Further support comes from findings that circulating plasma antibodies are more prevalent in female patients and that women display an increased immune response following immunization [110-116].

The immune response is altered following traumatic injury, and subsequent sepsis, multiple organ failure and mortality is occur more frequently [117-119] in males. Decreased survival rates and a higher frequency of infections and sepsis are reported by large analyses. A registry study of more than 680,000 patients demonstrated a decrease in complication and mortality rates after trauma [120]. A study that included more than 30,000 patients demonstrated that pneumonia is more frequent in males after traumatic injury [33]. Furthermore, in a prospective observational study of 2,183 patients and community-acquired pneumonia, older men had a lower survival rate [121].

Additionally, patients who have undergone surgery are more susceptible to infections. Wichmann et al. found a significant reduction in the number of immune-competent cells in postsurgical men [122]. Moreover, Offner et al. demonstrated gender dimorphism in the onset of postsurgical infections, with male gender as an independent risk factor [123]. The pathogenesis of immune system imbalance is multifactorial. The gender dimorphism is likely due to the divergent expression of pro- and anti-inflammatory cytokines. During sepsis, the secretion of proinflammatory cytokines such as IL-6, IL-8, IL-10, and TNF- $\alpha$, is increased in male patients [41, 124, 125].

Experimental studies further support these findings. Male mice subjected to polymicrobial sepsis by cecal ligation and puncture showed impaired survival rates compared to female mice [126]. In an experimental endotoxin model, male mice had significantly higher IL-1 blood levels after endotoxin injection [127]. In line with these findings are in vitro experiments with human peripheral blood mononuclear cells exposed to endotoxin. The authors demonstrated that proinflammatory TNF- $\alpha$ was significantly higher in endotoxemic male samples; however, administration of estrogen stimulated cytokine expression [128].

It is important to note that it is not the gender but specifically the sex hormones that influence outcome [129]. This is further underscored by the fact that the immune response is more pronounced during the proestrus phase compared to the diestrus phase [56, 130, 131]. Thus, exogenous administration of estrogen enhanced the ER- $\alpha$-mediated functions of macrophages and dendritic cells [132-134]. Treatment of septic male or ovariectomized female rats with ER- $\alpha$ agonists significantly attenuated sepsis-induced leukocyte-endothelial interactions (rolling, adherent leukocytes and neutrophil extravasation) and improved intestinal integrity [135]. Moreover, following trauma-hemorrhage and subsequent sepsis, administration of estrogen increased the activity of macrophages and survival rates [136].

\section{Discrepancy of clinical and experimental results}

Although the beneficial effects of estrogens on trauma, shock and sepsis have been demonstrated in various studies (Fig. 2), there remains a gap between the bench and the beside. Recently, a nationwide review indicated that female gender represents an independent risk factor for mortality in cases of spontaneous bacterial peritonitis [137]. These findings are in contrast to experimental and clinical results. Although patient number with more than 88,000 is high, those registry-based surveys do have some major limitations. Clinical studies mainly report on heterogeneous populations and are probably hampered by incomplete data sets. Most of these trials lack information regarding hormonal status at the time of

$17 \beta$-Estradiol administration following trauma and hemorrhage attenuates organ damage

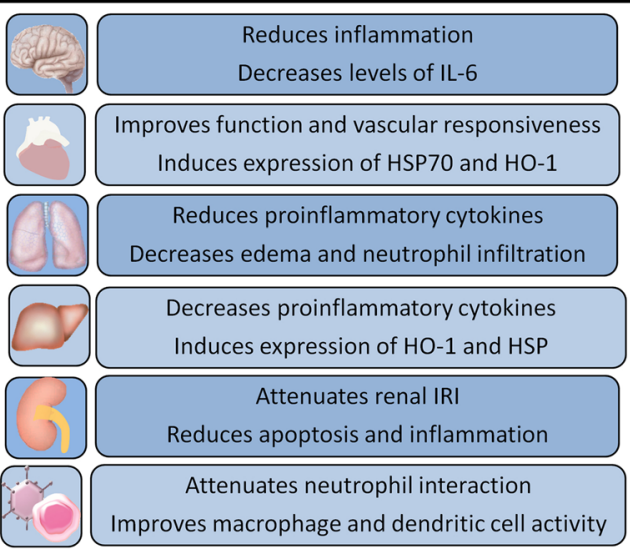

Fig. 2 Protective effects of $17 \beta$-estradiol on the CNS, heart, lung, liver, kidney and immune cells CNS: central nervous system; HSP: heat shock protein; HO-1: heme oxygenase-1; IRI: ischemiareperfusion injury; IL-6: interleukin-6 
injury or the onset of sepsis. Furthermore, information about intake of oral contraceptives, menstrual cycle status and hormone replacement therapy is not provided. Additionally, information should be provided if a female victim is pre- or postmenopausal.

In contrast, experimental studies provide a body of evidence indicating that estrogens are beneficial following adverse circulatory conditions. This might be due in part to the fact that most experimental studies were conducted using young male animals. Moreover, experimental studies follow a highly structured protocol in a homogenous cohort where the use of various agents such as fluid resuscitation (blood, crystalloids or plasma) can be easily defined and controlled, which is usually in contrast to the situations in trauma victims.

\section{Can estrogens be used to prolong permissive hypotension in the absence of fluid resuscitation?} Frequently, the transportation of the injured from remote areas may be hampered and it may take longer than the "golden hour" for the patient to reach a definitive care center. In light of this, attempts have been made to determine if the interval of permissive hypotension can be increased pharmacologically without fluid resuscitation. Experiments conducted in rats and minipigs showed that administration of estrogens (in a volume of $0.4 \mathrm{ml} / \mathrm{kg} \mathrm{BW}$ ) following major blood loss (60\% of the circulating blood volume) maintained permissive hypotension and improved survival rates of animals to over $50 \%$ for the examined period of up to 6 hours. Furthermore, if fluid resuscitation was provided at the end of the experiment, it resulted in long-term survival $[11,12,138,139]$. Thus, administration of estrogens can be carried out at the scene of an accident to stabilize the injured for transportation from rural areas to a definitive care facility for a period involving at least 3 hours. These findings therefore suggest that the so-called "golden hour" can be increased to at least 3 hours for transportation of the injured from the site of injury to definitive care treatment center.

With regards to the mechanism by which EES produces its salutary effects on cardiac functions in the absence of fluid resuscitation, studies have shown this hormone downregulated cardiac NF- $\mathrm{kB}$ and restored Nrf2 $30 \mathrm{~min}$ after EES administration. Furthermore, EES improved but did not restore left ventricular performance at this early interval after treatment. Thus, a major contributor to the beneficial effects of EES on cardiac function following blood loss in the absence of fluid resuscitation is probably via downregulation of cardiac nuclear NF- $\mathrm{kB}$ and restoration of cardiac nuclear Nrf2. Furthermore, the restoration of this signaling pathway occurs prior to restoration of cardiac functions [140].
Studies have also shown that major blood loss induces a significant increase in plasma nitrate/nitrite and aortic iNOS. In contrast, trauma-hemorrhage induces a significant decrease in aortic phospho-endothelial NOS (p-eNOS). These alterations correlated closely with trauma-hemorrhage-induced cardiac depression. EES treatment following trauma-hemorrhage downregulated the trauma-hemorrhage-induced increase in plasma nitrate/nitrite and aortic iNOS. Furthermore, it restored p-eNOS expression at 30 min after trauma-hemorrhage-MBO, even in the absence of fluid resuscitation. Thus, the salutary effects of EES on cardiac function following severe blood loss in the absence of fluid resuscitation are linked to the normalization of plasma nitrate/nitrite concentrations, aortic iNOS and restoration of p-eNOS expression [29].

Studies have shown that administration of ICI 182,780 (estrogen receptor antagonist) $30 \mathrm{~min}$ prior to EES completely abolished the salutary effect of EES on cardiac function. Furthermore, the specific ER- $\beta$ antagonist PHTPP, but not the specific ER- $\alpha$ antagonist MPP, completely abrogated the salutary effect of EES on cardiac function at $30 \mathrm{~min}$ post-MBO. Thus, the beneficial effects of EES on cardiac function following severe blood loss without fluid resuscitation occur via cardiac estrogen receptors and primarily via cardiac ER- $\beta$ [141].

Additional studies have shown that trauma-hemorrhage induced a significant decrease in cardiac Bcl-2 and a significant increase in cardiac Caspase- 3 and -8 . Both signaling alterations were closely correlated with $\mathrm{T}$-H-induced cardiac depression. EES treatment following trauma-hemorrhage without fluid resuscitation restored cardiac $\mathrm{Bcl}-2$ and the trauma-hemorrhage-induced increase in cardiac Caspase- 3 and -8 . Thus, the major contributing factor to the beneficial effect of EES on cardiac function following severe blood loss appears to be induced via the inhibition of $\mathrm{T}-\mathrm{H}$-induced cardiac apoptosis, mediated by restoration of cardiac $\mathrm{Bcl}-2$ and normalization of the T-H-induced increase in cell death signaling pathways [142].

\section{Conclusion}

An abundance of evidence exists highlighting the salutary effects of estrogens following adverse circulatory conditions. Studies reveal that estrogens beneficially influence cytokine release, chemotaxis of neutrophils, expression of HSP, induction of HO-1 and the restoration of organ function following shock and sepsis. Accordingly, estrogens contribute to the higher survival rates in the aforementioned studies. The exact mechanism by which estrogen exerts its beneficial immunomodulatory effects has not been fully elucidated until now. However, there are studies reporting direct and indirect synergistic effects on signaling mechanisms and pathways. Since the hormonal milieu rather than gender influences outcomes after trauma and sepsis, prospective clinical trials are needed to address this 
issue. It should also be noted that estrogens may be used to prolong the permissive hypotension period and thus aid in the prolonged transportation of the injured from the scene of the accident.

The consideration of gender and sex hormone status for treatment in the clinical arena represents an important and novel step towards personalized medicine.

\begin{abstract}
Abbreviations
AKI: Acute kidney; AP-1: Activating protein-1; ATP: Adenosine triphosphate; CINC-x: Cytokine-induced neutrophil chemoattractant x; EES: Ethynyl ethinyl estradiol-3sulfate 3 sulfate; ERK: Extracellular signal-regulated protein kinase; ER-a: Estradiol receptor-a; GPR30: G protein-coupled receptor 30; HO1: Heme oxygenase-1; HSP: Heat shock protein; ICAM-1: Intercellular adhesion molecule-1; IL-x: Interleukin-x; iNOS: Inducible nitric oxide synthase; IRI: Ischemia-reperfusion injury; MAPK: Mitogen activated protein kinase; $p$ eNOS: Phospho-endothelial nitric oxide synthase; TBI: Traumatic brain injury; TLR4: Toll-like receptor 4; TNF-a: Tumor necrosis factor-a
\end{abstract}

\section{Funding}

Supported in part by US DoD Contract \#W911QY-15-C-0134

\section{Authors' contributions}

FB was responsible for drafting and writing of the article. IHC and MKA were involved in drafting and revising the manuscript. All authors read and approved the final manuscript.

\section{Ethics approval and consent to participate}

Not applicable

\section{Consent for publication}

Not applicable

\section{Competing interests}

The authors declare that they have no conflicts of interest.

\section{Author details}

'Department of General, Visceral, and Transplant Surgery, Ludwig

Maximilians-University Munich, 81377 Munich, Germany. ${ }^{2}$ Center for Surgical Research and Department of Surgery, University of Alabama at Birmingham Birmingham, AL 35294, USA

Received: 10 June 2018 Accepted: 4 October 2018

Published online: 26 October 2018

\section{References}

1. Ren C, Zhang H, Wu TT, Yao YM. Autophagy: A potential therapeutic target for reversing sepsis-induced immunosuppression. Front Immunol. 2017;8:1832

2. Runge JW. The cost of injury. Emerg Med Clin North Am. 1993;11(1):241-53.

3. Faul M, Coronado V. Epidemiology of traumatic brain injury. Handbook Clin Neurol. 2015;127:3-13.

4. Rossaint R, Cerny V, Coats TJ, Duranteau J, Fernandez-Mondejar E, Gordini G, et al. Key issues in advanced bleeding care in trauma. Shock. 2006;26(4): 322-31.

5. Rutland-Brown W, Langlois JA, Thomas KE, Xi YL. Incidence of traumatic brain injury in the united states, 2003. J Head Trauma Rehabil. 2006;21(6): 544-8.

6. Ma VY, Chan L, Carruthers KJ. Incidence, prevalence, costs, and impact on disability of common conditions requiring rehabilitation in the united states: Stroke, spinal cord injury, traumatic brain injury, multiple sclerosis, osteoarthritis, rheumatoid arthritis, limb loss, and back pain. Arch Phys Med Rehabil. 2014;95(5):986-95.

7. Eastridge BJ, Hardin M, Cantrell J, Oetjen-Gerdes L, Zubko T, Mallak C, et al. Died of wounds on the battlefield: Causation and implications for improving combat casualty care. J Trauma. 2011;71(1):S4-8.

8. Eastridge BJ, Mabry RL, Seguin P, Cantrell J, Tops T, Uribe P, et al. Death on the battlefield (2001-2011): Implications for the future of combat casualty care. J Trauma Acute Care Surg. 2012;73(6 5):S431-7.
9. Schadt JC, Ludbrook J. Hemodynamic and neurohumoral responses to acute hypovolemia in conscious mammals. Am J Physiol. 1991;260(2 2): H305-18.

10. Weniger $\mathrm{M}$, Angele MK, Chaudry $\mathrm{H}$. The role and use of estrogens following trauma. Shock. 2016;46(1):4-11.

11. Hubbard W, Keith J, Berman J, Miller M, Scott C, Peck C, et al. 17alphaethynylestradiol-3-sulfate treatment of severe blood loss in rats. J Surg Res. 2015;193(1):355-60

12. Miller M, Keith J, Berman J, Burlington DB, Grudzinskas C, Hubbard W, et al. Efficacy of 17alpha-ethynylestradiol-3-sulfate for severe hemorrhage in minipigs in the absence of fluid resuscitation. J Trauma Acute Care Surg. 2014;76(6):1409-16.

13. Levy MM, Dellinger RP, Townsend SR, Linde-Zwirble WT, Marshall JC, Bion J, et al. The surviving sepsis campaign: Results of an international guidelinebased performance improvement program targeting severe sepsis. Intensive Care Med. 2010;36(2):222-31

14. Angus DC, Linde-Zwirble WT, Lidicker J, Clermont G, Carcillo J, Pinsky MR. Epidemiology of severe sepsis in the United States: Analysis of incidence, outcome, and associated costs of care. Crit Care Med. 2001:29(7):1303-10

15. Zhu Z, Shang X, QI P, Ma S. Sex-based differences in outcomes after severe injury: an analysis of blunt trauma patients in China. Scand J Trauma Resusc Emerg Med. 2017;25(1):47.

16. Wen Q, Su L. Impact of gender and age on multiple organ dysfunction syndrome and inflammatory cytokines after multiple injuries. J Southern Med Uni. 2009;29(2):253-5.

17. Du XH, Yao YM, Li R, Shen CA, Yin HN. Influence of sexual difference on expression of toll-like receptor 4 and myeloid differential protein-2 mRNA in the lung in septic rats. China Crit Care Med. 2005;17(12):726-8.

18. Wang DW, Yin YM, Yao YM. Vagal modulation of the inflammatory response in sepsis. Int Rev Immunol. 2016;35(5):415-33.

19. Li T, Xiao X, Zhang J, Zhu Y, Hu Y, Zang J, et al. Age and differences in vascular responsiveness in healthy and trauma patients: Contribution of estrogen receptor-mediated Rho kinase and PKC pathways. Am J Physiol Heart Circ Physiol. 2014:306(8):H1105-15.

20. Xiao J, Zhang J, Zhao Y, Huang W, Guo Z, SU B, et al. Sex differences of steroid receptor coactivator-1 expression after spinal cord injury in mice. Neurol Res. 2017;39(11):1022-7.

21. Bone RC. Toward an epidemiology and natural history of sirs (systemic inflammatory response syndrome). JAMA. 1992:268(24):3452-5.

22. George RL, McGwin G Jr, Windham ST, Melton SM, Metzger J, Chaudry IH, et al. Age-related gender differential in outcome after blunt or penetrating trauma. Shock. 2003;19(1):28-32.

23. Kher A, Wang M, Tsai BM, Pitcher JM, Greenbaum ES, Nagy RD, et al. Sex differences in the myocardial inflammatory response to acute injury. Shock. 2005;23(1):1-10

24. Liu T, Xie J, Yang F, Chen JJ, Li ZF, Yi CL, et al. The influence of sex on outcomes in trauma patients: A meta-analysis. Am J Surg. 2015;210(5): $911-21$

25. Angele MK, Schwacha MG, Ayala A, Chaudry $\mathbb{H}$. Effect of gender and sex hormones on immune responses following shock. Shock. 2000;14(2):81-90.

26. Yu HP, Chaudry IH. The role of estrogen and receptor agonists in maintaining organ function after trauma-hemorrhage. Shock. 2009:31(3): 227-37.

27. Breithaupt-Faloppa AC, Thais Fantozzi E, Romero DC, Rodrigues Ada S, de Sousa PT. Lino Dos Santos Franco A, et al. Acute effects of estradiol on lung inflammation due to intestinal ischemic insult in male rats. Shock. 2014; 41(3):208-13.

28. Hu S, Yang S, Hubbard WJ, Bland K, Chaudry I. Salutary effect of estrogen are mediated mainly via estrogen receptor (ER)- $\beta$ in the heart but via estrogen receptor (ER)-a in the liver following trauma-hemorrhagic shock (T-H). Shock. 2016;45(1):46.

29. Yang S, Hu S, Yu T, Hubbard WJ, Chaudry IH. Surviving blood loss without fluid resuscitation: cardiac estrogen receptor beta (ER- $\beta$ ) plays a vital role in improving cardiac functions following EE-3-SO ${ }_{4}$ administration. Shock. 2017; 47(1):47-8.

30. Pena G, Michalski C, Donnelly RJ, Qin Y, Sifri ZC, Mosenthal AC, et al. Trauma-induced acute $\mathrm{x}$ chromosome skewing in white blood cells represents an immuno-modulatory mechanism unique to females and a likely contributor to sex-based outcome differences. Shock. 2017:47(4):402-8. 
31. Spolarics Z. The $x$-files of inflammation: Cellular mosaicism of $x$-linked polymorphic genes and the female advantage in the host response to injury and infection. Shock. 2007;27(6):597-604.

32. McGowan JE Jr, Barnes MW, Finland M. Bacteremia at Boston city hospital: Occurrence and mortality during 12 selected years (1935-1972), with special reference to hospital-acquired cases. J Infect Dis. 1975;132(3):316-35

33. Gannon CJ, Pasquale M, Tracy JK, McCarter RJ, Napolitano LM. Male gender is associated with increased risk for postinjury pneumonia. Shock. 2004; 21(5):410-4.

34. Wichmann MW, Inthorn D, Andress HJ, Schildberg FW. Incidence and mortality of severe sepsis in surgical intensive care patients: The influence of patient gender on disease process and outcome. Intensive Care Med. 2000;26(2):167-72.

35. Mörs K, Braun O, Wagner N, Auner B, Voth M, Störmann P, et al. Influence of gender on systemic IL-6 levels, complication rates and outcome after major trauma. Immunobiology. 2016;221:904-10.

36. Eachempati SR, Hydo L, Barie PS. Gender-based differences in outcome in patients with sepsis. Arch Surg. 1999:134(12):1342-7.

37. Napolitano LM, Greco ME, Rodriguez A, Kufera JA, West RS, Scalea TM. Gender differences in adverse outcomes after blunt trauma. J Trauma. 2001; 50(2):274-80.

38. Sakr Y, Elia C, Mascia L, Barberis B, Cardellino S, Livigni S, et al. The influence of gender on the epidemiology of and outcome from severe sepsis. Critical Care. 2013;17:R50.

39. George RL, McGwin G Jr, Metzger J, Chaudry IH, Rue LW. The association between gender and mortality among trauma patients as modified by age. J Trauma. 2003;54(3):464-71.

40. Wohltmann CD, Franklin GA, Boaz PW, Luchette FA, Kearney PA, Richardson $J D$, et al. A multicenter evaluation of whether gender dimorphism affects survival after trauma. Am J Surg. 2001;181(4):297-300.

41. Frink M, Pape HC, van Griensven $M$, Krettek C, Chaudry $I H$, Hildebrand F. Influence of sex and age on mods and cytokines after multiple injuries. Shock. 2007;27(2):151-6.

42. Mostafa G, Huynh T, Sing RF, Miles WS, Norton HJ, Thomason MH. Genderrelated outcomes in trauma. J Trauma. 2002;53(3):430-4 discussion 4-5.

43. Failla KR, Connelly CD. Systematic review of gender differences in sepsis management and outcomes. J Nurs Scholarsh. 2017:49(3):312-24.

44. Gujral IB, Stallones L, Gabella BA, Keefe TJ, Chen P. Sex differences in mortality after traumatic brain injury, Colorado 1994-1998. Brain Inj. 2006;20(3):283-91.

45. Ng I, Lee KK, Lim JH, Wong HB, Yan XY. Investigating gender differences in outcome following severe traumatic brain injury in a predominantly Asian population. Br J Neurosurg. 2006;20(2):73-8.

46. Papathanassoglou E, Middleton N, Benbenishty J, Williams G, Christofi MD, Hegadoren K. Systematic review of gender- dependent outcomes in sepsis. Nurs Crit Care. 2017;22(5):284-92.

47. van Noord PA, Dubas JS, Dorland M, Boersma H, te Velde E. Age at natural menopause in a population-based screening cohort: The role of menarche, fecundity, and lifestyle factors. Fertil Steril. 1997;68(1):95-102.

48. Hersh AL, Stefanick ML, Stafford RS. National use of postmenopausal hormone therapy: Annual trends and response to recent evidence. JAMA. 2004;291(1):47-53.

49. Baumann H, Gauldie J. The acute phase response. Immunol Today. 1994 15(2):74-80.

50. Blandino P Jr, Barnum CJ, Deak T. The involvement of norepinephrine and microglia in hypothalamic and splenic il-1beta responses to stress. J Neuroimmunol. 2006;173(1-2):87-95.

51. Skaper SD. The brain as a target for inflammatory processes and neuroprotective strategies. Ann N Y Acad Sci. 2007;1122:23-34.

52. Engler-Chiurazzi EB, Brown CM, Povroznik JM, Simpkins JW. Estrogens as neuroprotectants: Estrogenic actions in the context of cognitive aging and brain injury. Prog Neurobiol. 2017;157:188-211.

53. Maas Al, Stocchetti N, Bullock R. Moderate and severe traumatic brain injury in adults. Lancet Neurol. 2008;7(8):728-41.

54. Ashdown H, Poole S, Boksa P, Luheshi GN. Interleukin-1 receptor antagonist as a modulator of gender differences in the febrile response to lipopolysaccharide in rats. Am J Physiol Regul Integr Comp Physiol. 2007; 292(4):R1667-74

55. Avitsur R, Donchin O, Barak O, Cohen E, Yirmiya R. Behavioral effects of interleukin-1 beta: Modulation by gender, estrus cycle, and progesterone. Brain Behav Immun. 1995;9(3):234-41.
56. Arakawa K, Arakawa H, Hueston CM, Deak T. Effects of the estrous cycle and ovarian hormones on central expression of interleukin-1 evoked by stress in female rats. Neuroendocrinology. 2014;100(2-3):162-77.

57. Kim H, Cam-Etoz B, Zhai G, Hubbard WJ, Zinn KR, Chaudry IH. Salutary effects of estrogen sulfate for traumatic brain injury. J Neurotrauma. 2015;32: 1210-6.

58. Hubbard WJ, Chaudry $\mathbb{H}_{\text {. The }}$. use of estrogen for the treatment of traumatic brain injury. In: Heidenreich K, editor. In new therapeutics for traumatic brain injury: prevention of secondary brain damage and enhancement of repair and regeneration. Cambridge: Academic Press; 2016. p. 161-77.

59. Kim H, Yu T, Cam-Etoz B, Groen TV, Hubbard WJ, Chaudry IH. Treatment of traumatic brain injury with 17-a-ethinylestradiol-3-sulfate in a rat model. J Neurosurg. 2017;127:23-31.

60. Cuzzocrea S, Genovese T, Mazzon E, Esposito E, Paola RD, Muià C, Crisafulli C, Peli A, Bramanti P, Chaudry IH. Effect of $17 \beta$-estradiol on signal transduction pathways and secondary damage in experimental spinal cord trauma. Shock. 2008:29:362-71.

61. Namjoo Z, Moradi F, Aryanpour R, Piryaei A, Joghataei MT, Abbasi Y, Hosseini A, et al. Combined effects of rat Schwann cells and 17ß-estradiol in a spinal cord injury model. Metab Brain Dis. 2018;33(4):1229-42.

62. Li T, Xiao X, Zhang J, Zhu Y, Hu Y, Zang J, et al. Age and sex differences in vascular responsiveness in healthy and trauma patients: Contribution of estrogen receptor-mediated Rho kinase and PKC pathways. Am J Physiol Heart Circ Physiol. 2014;306(8):H1105-15.

63. Soliman M. Protective effects of estradiol on myocardial contractile function following hemorrhagic shock and resuscitation in rats. Chin Med J (Engl). 2015;128(17):2360-4

64. Dhamad AE, Zhou Z, Zhou J, Du Y. Systematic proteomic identification of the heat shock proteins (HSP) that interact with estrogen receptor alpha (ERalpha) and biochemical characterization of the eralpha-hsp70 interaction. PLoS One. 2016;11(8):e0160312

65. Wang JL, Ke DS, Lin MT. Heat shock pretreatment may protect against heatstroke-induced circulatory shock and cerebral ischemia by reducing oxidative stress and energy depletion. Shock. 2005:23(2):161-7.

66. Hsu JT, Hsieh YC, Kan WH, Chen JG, Choudhry MA, Schwacha MG, et al. Role of p38 mitogen-activated protein kinase pathway in estrogenmediated cardioprotection following trauma-hemorrhage. Am J Physiol Heart Circ Physiol. 2007:292(6):H2982-7.

67. Szalay L, Shimizu T, Suzuki T, Yu HP, Choudhry MA, Schwacha MG, et al. Estradiol improves cardiac and hepatic function after trauma-hemorrhage: Role of enhanced heat shock protein expression. Am J Physiol Regul Integr Comp Physiol. 2006;290(3):R812-8.

68. Yu HP, Shimizu T, Choudhry MA, Hsieh YC, Suzuki T, Bland Kl, et al. Mechanism of cardioprotection following trauma-hemorrhagic shock by a selective estrogen receptor-beta agonist: Up-regulation of cardiac heat shock factor-1 and heat shock proteins. J Mol Cell Cardiol. 2006;40(1):185-94.

69. Bosch F, Thomas M, Kogler P, Oberhuber R, Sucher R, Aigner F, et al. Bilirubin rinse of the graft ameliorates ischemia reperfusion injury in heart transplantation. Transpl Int. 2014:27(5):504-13.

70. Otterbein LE, Foresti R, Motterlini R. Heme oxygenase-1 and carbon monoxide in the heart: The balancing act between danger signaling and pro-survival. Circ Res. 2016;118(12):1940-59.

71. Franconi F, Rosano G, Basili S, Montella A, Campesi I. Human cells involved in atherosclerosis have a sex. Int J Cardiol. 2017;228:983-1001.

72. Kannel WB, Wilson PW, D'Agostino RB, Cobb J. Sudden coronary death in women. Am Heart J. 1998;136(2):205-12.

73. Vitale C, Mendelsohn ME, Rosano GM. Gender differences in the cardiovascular effect of sex hormones. Nat Rev Cardiol. 2009;6(8):532-42.

74. Dayal SD, Hasko G, Lu Q, Xu DZ, Caruso JM, Sambol JT, et al. Trauma/ hemorrhagic shock mesenteric lymph upregulates adhesion molecule expression and il-6 production in human umbilical vein endothelial cells. Shock. 2002;17(6):491-5.

75. Yu HP, Yang S, Hsieh YC, Choudhry MA, Bland Kl, Chaudry IH. Maintenance of lung myeloperoxidase activity in proestrus females after traumahemorrhage: Upregulation of heme oxygenase-1. Am J Physiol Lung Cell Mol Physiol. 2006;291(3):L400-6.

76. Caruso JM, Xu DZ, Lu Q, Dayal SD, Deitch EA. The female gender protects against pulmonary injury after trauma hemorrhagic shock. Surg Infect (Larchmt). 2001;2(3):231-40.

77. Frink M, Thobe BM, Hsieh YC, Choudhry MA, Schwacha MG. Bland Kl, et al. 17beta-estradiol inhibits keratinocyte-derived chemokine production 
following trauma-hemorrhage. Am J Physiol Lung Cell Mol Physiol. 2007; 292(2):L585-91.

78. Doucet D, Badami C, Palange D, Bonitz RP, Lu Q, Xu DZ, et al. Estrogen receptor hormone agonists limit trauma hemorrhage shock-induced gut and lung injury in rats. PLoS One. 2010;5(2):e9421.

79. Hsu JT, Kan WH, Hsieh CH, Choudhry MA, Bland Kl, Chaudry IH. Role of extracellular signal-regulated protein kinase (ERK) in 17beta-estradiolmediated attenuation of lung injury after trauma-hemorrhage. Surgery. 2009;145(2):226-34.

80. van den Berg HR, Khan NA, van der Zee M, Bonthuis F, JN IJ, Dik WA, et al. Synthetic oligopeptides related to the [beta]-subunit of human chorionic gonadotropin attenuate inflammation and liver damage after (trauma) hemorrhagic shock and resuscitation. Shock. 2009;31(3):285-91.

81. Korff S, Loughran P, Cai C, Lee YS, Scott M, Billiar TR. Eritoran attenuates tissue damage and inflammation in hemorrhagic shock/trauma. J Surg Res. 2013;184(2):e17-25.

82. Wannemuehler TJ, Manukyan MC, Brewster BD, Rouch J, Poynter JA, Wang $Y$, et al. Advances in mesenchymal stem cell research in sepsis. J Surg Res. 2012;173(1):113-26.

83. Chen X, Zhang J, Han C, Dai H, Kong X, Xu L, et al. A sexual dimorphism influences bicyclol-induced hepatic heat shock factor 1 activation and hepatoprotection. Mol Pharmacol. 2015;88(1):38-47.

84. Erikoglu M, Sahin M, Ozer S, Avunduk MC. Effects of gender on the severity of sepsis. Surg Today. 2005;35(6):467-72.

85. Sener G, Arbak S, Kurtaran P, Gedik N, Yegen BC. Estrogen protects the liver and intestines against sepsis-induced injury in rats. J Surg Res. 2005;128(1):70-8.

86. Suzuki T, Shimizu T, Yu HP, Hsieh YC, Choudhry MA. Bland Kl, et al. 17 betaestradiol administration following trauma-hemorrhage prevents the increase in Kupffer cell cytokine production and MAPK activation predominately via estrogen receptor-alpha. Surgery. 2006;140(2):141-8.

87. Yokoyama Y, Kuebler JF, Matsutani T, Schwacha MG, Bland Kl, Chaudry IH. Mechanism of the salutary effects of 17beta-estradiol following traumahemorrhage: Direct downregulation of Kupffer cell proinflammatory cytokine production. Cytokine. 2003;21(2):91-7.

88. Bosch F, Tsui TY. Carbon monoxide, a two-face for the protection of the liver. Curr Pharm Biotechnol. 2012;13(6):803-12.

89. Liu FC, Yu HP, Hwang TL, Tsai YF. Protective effect of tropisetron on rodent hepatic injury after trauma-hemorrhagic shock through p38 MAPKdependent hemeoxygenase-1 expression. PLoS One. 2012;7(12):e53203.

90. Hsu JT, Kan WH, Hsieh CH, Choudhry MA, Schwacha MG, Bland KI, et al. Mechanism of estrogen-mediated attenuation of hepatic injury following trauma-hemorrhage: Akt-dependent HO-1 up-regulation. J Leukoc Biol. 2007;82(4):1019-26.

91. Hsu JT, Chen TH, Chiang KC, Kuo CJ, Lin CJ, Yeh TS. Role of p38 MAPK pathway in 17beta-estradiol-mediated attenuation of hemorrhagic shockinduced hepatic injury. J Appl Physiol. 2015;118(2):187-92.

92. Hsieh YC, Frink M, Kawasaki T, Thobe BM, Choudhry MA, Schwacha MG, et al. Downregulation of TLR4-dependent ATP production is critical for estrogen-mediated immunoprotection in Kupffer cells following traumahemorrhage. J Cell Physiol. 2007;211(2):364-70

93. Hsieh YC, Frink M, Thobe BM, Hsu JT, Choudhry MA, Schwacha MG, et al. 17beta-estradiol downregulates Kupffer cell TLR4-dependent p38 MAPK pathway and normalizes inflammatory cytokine production following trauma-hemorrhage. Mol Immunol. 2007:44(9):2165-72.

94. Menezes JM, Hierholzer C, Watkins SC, Billiar TR, Peitzman AB, Harbrecht BG. The modulation of hepatic injury and heat shock expression by inhibition of inducible nitric oxide synthase after hemorrhagic shock. Shock. 2002;17(1):13-8.

95. Shimizu T, Yu HP, Suzuki T, Szalay L, Hsieh YC, Choudhry MA, et al. The role of estrogen receptor subtypes in ameliorating hepatic injury following trauma-hemorrhage. J Hepatol. 2007:46(6):1047-54.

96. Eckhoff DE, Bilbao G, Frenette L, Thompson JA, Contreras JL. 17-betaestradiol protects the liver against warm ischemia/reperfusion injury and is associated with increased serum nitric oxide and decreased tumor necrosis factor-alpha. Surgery. 2002;132(2):302-9.

97. Shen SQ, Zhang Y, Xiong CL. The protective effects of 17beta-estradiol on hepatic ischemia-reperfusion injury in rat model, associated with regulation of heat-shock protein expression. J Surg Res. 2007;140(1):67-76.

98. Yu HP, Shimizu T, Hsieh YC, Suzuki T, Choudhry MA, Schwacha MG, et al. Tissue-specific expression of estrogen receptors and their role in the regulation of neutrophil infiltration in various organs following traumahemorrhage. J Leukoc Biol. 2006:79(5):963-70.

99. Shimizu T, Yu HP, Hsieh YC, Choudhry MA, Suzuki T, Bland Kl, et al. Flutamide attenuates pro-inflammatory cytokine production and hepatic injury following trauma-hemorrhage via estrogen receptor-related pathway. Ann Surg. 2007;245(2):297-304.

100. Hsieh YC, Yu HP, Frink M, Suzuki T, Choudhry MA, Schwacha MG, et al. G protein-coupled receptor 30-dependent protein kinase a pathway is critical in nongenomic effects of estrogen in attenuating liver injury after traumahemorrhage. Am J Pathol. 2007;170(4):1210-8.

101. Kim WY, Huh JW, Lim CM, Koh Y, Hong SB. Analysis of progression in risk, injury, failure, loss, and end-stage renal disease classification on outcome in patients with severe sepsis and septic shock. J Crit Care. 2012;27(1):104 e1-7.

102. Plataki M, Kashani K, Cabello-Garza J, Maldonado F, Kashyap R, Kor DJ, et al. Predictors of acute kidney injury in septic shock patients: An observational cohort study. Clin J Am Soc Nephrol. 2011;6(7):1744-51.

103. Bonventre JV, Zuk A. Ischemic acute renal failure: An inflammatory disease? Kidney Int. 2004;66(2):480-5.

104. Ferenbach DA, Kluth DC, Hughes J. Hemeoxygenase-1 and renal ischaemiareperfusion injury. Nephron Exp Nephrol. 2010;115(3):e33-7.

105. Thadhani R, Pascual M, Bonventre JV. Acute renal failure. N Engl J Med. 1996;334(22):1448-60

106. Rusai K, Prokai A, Szebeni B, Meszaros K, Fekete A, Szalay B, et al. Gender differences in serum and glucocorticoid regulated kinase-1 (sgk-1) expression during renal ischemia/reperfusion injury. Cell Physiol Biochem. 2011;27(6):727-38

107. Satake A, Takaoka M, Nishikawa M, Yuba M, Shibata Y, Okumura K, et al. Protective effect of 17 beta-estradiol on ischemic acute renal failure through the PI3K/AKT/eNOS pathway. Kidney Int. 2008;73(3):308-17.

108. Wu CC, Chang CY, Chang ST, Chen SH. 17beta-estradiol accelerated renal tubule regeneration in male rats after ischemia/reperfusion-induced acute kidney injury. Shock. 2016;46(2):158-63.

109. Kasimay O, Sener G, Cakir B, Yuksel M, Cetinel S, Contuk G, et al. Estrogen protects against oxidative multiorgan damage in rats with chronic renal failure. Ren Fail. 2009;31(8):711-25.

110. Sherlock S, Scheuer PJ. The presentation and diagnosis of 100 patients with primary biliary cirrhosis. N Engl J Med. 1973;289(13):674-8.

111. Roubinian JR, Talal N, Greenspan JS, Goodman JR, Siiteri PK. Effect of castration and sex hormone treatment on survival, anti-nucleic acid antibodies, and glomerulonephritis in NZB/NZW F1 mice. J Exp Med. 1978; 147(6):1568-83

112. Pace S, Sautebin L, Werz O. Sex-biased eicosanoid biology: Impact for sex differences in inflammation and consequences for pharmacotherapy. Biochem Pharmacol. 2017;145:1-11.

113. Olsen NJ, Kovacs WJ. Gonadal steroids and immunity. Endocr Rev. 1996; 17(4):369-84.

114. Klein SL, Flanagan KL. Sex differences in immune responses. Nat Rev Immunol. 2016;16(10):626-38.

115. Hochberg MC, Spector TD. Epidemiology of rheumatoid arthritis: Update. Epidemiol Rev. 1990;12:247-52.

116. Franks CR. Letter: Hormone exposure and lymphocytic impairment. JAMA. 1975;232(1):19-20

117. Baue AE. MOF, MODS, and SIRS: What is in a name or an acronym? Shock. 2006;26(5):438-49,

118. Shukla A, Hashiguchi N, Chen Y, Coimbra R, Hoyt DB, Junger WG. Osmotic regulation of cell function and possible clinical applications. Shock. 2004; 21(5):391-400

119. Ulloa L, Tracey KJ. The "cytokine profile": A code for sepsis. Trends Mol Med. 2005:11(2):56-63.

120. Haider AH, Crompton JG, Oyetunji T, Stevens KA, Efron DT, Kieninger AN, et al. Females have fewer complications and lower mortality following trauma than similarly injured males: A risk adjusted analysis of adults in the national trauma data bank. Surgery. 2009;146(2):308-15.

121. Reade MC, Yende S, D'Angelo G, Kong L, Kellum JA, Barnato AE, et al. Differences in immune response may explain lower survival among older men with pneumonia. Crit Care Med. 2009;37(5):1655-62.

122. Wichmann MW, Muller C, Meyer G, Adam M, Angele MK, Eisenmenger SJ, et al. Different immune responses to abdominal surgery in men and women. Langenbecks Arch Surg. 2003;387(11-12):397-401.

123. Offner PJ, Moore EE, Biffl WL. Male gender is a risk factor for major infections after surgery. Arch Surg. 1999;134(9):935-8. 
124. Aulock SV, Deininger S, Draing C, Gueinzius K, Dehus O, Hermann C. Gender difference in cytokine secretion on immune stimulation with LPS and ITA. J Interferon Cytokine Res. 2006;26(12):887-92.

125. Oberholzer A, Keel M, Zellweger R, Steckholzer U, Trentz O, Ertel W. Incidence of septic complications and multiple organ failure in severely injured patients is sex specific. J Trauma. 2000;48(5):932-7.

126. Zellweger R, Wichmann MW, Ayala A, Stein S, DeMaso CM, Chaudry IH. Females in proestrus state maintain splenic immune functions and tolerate sepsis better than males. Crit Care Med. 1997;25(1):106-10.

127. Li P, Allen H, Banerjee S, Franklin S, Herzog L, Johnston C, et al. Mice deficient in il-1 beta-converting enzyme are defective in production of mature il-1 beta and resistant to endotoxic shock. Cell. 1995;80(3):401-11.

128. Asai K, Hiki N, Mimura Y, Ogawa T, Unou K, Kaminishi M. Gender differences in cytokine secretion by human peripheral blood mononuclear cells: Role of estrogen in modulating LPSW-induced cytokine secretion in an ex vivo septic model. Shock. 2001;16(5):340-3.

129. Angele MK, Pratschke S, Hubbard WJ, Chaudry IH. Gender differences in sepsis: Cardiovascular and immunological aspects. Virulence. 2014;5(1):12-9.

130. Ananthakrishnan P, Cohen DB, Xu DZ, Lu Q, Feketeova E, Deitch EA. Sex hormones modulate distant organ injury in both a trauma/hemorrhagic shock model and a burn model. Surgery. 2005;137(1):56-65.

131. Krzych U, Strausser HR, Bressler JP, Goldstein AL. Effects of sex hormones on some $t$ and $b$ cell functions, evidenced by differential immune expression between male and female mice and cyclic pattern of immune responsiveness during the estrous cycle in female mice. Am J Reprod Immunol. 1981:1(2):73-7.

132. Friedman D, Netti F, Schreiber AD. Effect of estradiol and steroid analogues on the clearance of immunoglobulin g-coated erythrocytes. J Clin Invest. 1985;75(1):162-7.

133. Suzuki T, Shimizu T, Yu HP, Hsieh YC, Choudhry MA, Bland Kl, et al. Estrogen receptor-alpha predominantly mediates the salutary effects of 17 betaestradiol on splenic macrophages following trauma-hemorrhage. Am J Physiol Cell Physiol. 2007;293(3):C978-84.

134. Lambert KC, Curran EM, Judy BM, Lubahn DB, Estes DM. Estrogen receptoralpha deficiency promotes increased TNF-alpha secretion and bacterial killing by murine macrophages in response to microbial stimuli in vitro. J Leukoc Biol. 2004;75(6):1166-72.

135. Sharawy N, Ribback S, Al-Banna N, Lehmann C, Kern H, Wendt M, et al. Estradiol receptors agonists induced effects in rat intestinal microcirculation during sepsis. Microvasc Res. 2013;85:118-27.

136. Knoferl MW, Diodato MD, Angele MK, Ayala A, Cioffi WG, Bland Kl, et al. Do female sex steroids adversely or beneficially affect the depressed immune responses in males after trauma-hemorrhage? Arch Surg. 2000;135(4):425-33.

137. Niu B, Kim B, Limketkai BN, Sun J, Li Z, Woreta T, et al. Mortality from spontaneous bacterial peritonitis among hospitalized patients in the USA. Dig Dis Sci. 2018;63(5):1327-33.

138. Chen JG, Not L, Ng T, Hubbard WJ, Chatham J, Choudhry MA, et al. 17ßestradiol (E2) administration after major blood loss improves liver ATP, 3 hour survival and also long-term survival following prolonged hypotension (3 hour) and fluid resuscitation. Shock. 2006;25(6):11.

139. Kim H, Chen J, Zinn KR, Chaudry IH. Single photon emission computed tomography demonstrated efficacy of $17 \beta$-estradiol therapy in male rats following trauma-hemorrhage and extended hypotension. J Trauma. 2010; 69(5):1266-73.

140. Hu S, Yang S, Yu T, Hubbard WJ, Chaudry IH. Surviving blood loss without fluid resuscitation: $\mathrm{EE}-3-\mathrm{SO}_{4}$ restores cardiac cellular signaling ahead of cardiac functions. Shock. 2017:47(6):47-8.

141. Yang S, Hu S, Hubbard WJ, Chaudry H. Ethinyl estradiol-3-SO4 (EE-3-SO4) improves cardiovascularfunctions after trauma-hemorrhage $(T-H)$ in the absence of fluid resuscitation by normalizing aortic iNOS expression/plasma nitrite/nitrite levels. Shock. 2018:49(Suppl 1):119-20

142. Hu S, Yang S, Hubbard WJ, Chaudry IH. Surviving blood loss following trauma-hemorrhage $(\mathrm{T}-\mathrm{H})$ inthe absence of fluid resuscitation: EE-3-SO4 inhibits apoptosis and regularizes T-H-induced cell death pathways. Shock. 2018:49(Suppl 1):119.

\section{Ready to submit your research? Choose BMC and benefit from:}

- fast, convenient online submission

- thorough peer review by experienced researchers in your field

- rapid publication on acceptance

- support for research data, including large and complex data types

- gold Open Access which fosters wider collaboration and increased citations

- maximum visibility for your research: over $100 \mathrm{M}$ website views per year

At BMC, research is always in progress.

Learn more biomedcentral.com/submissions 